REFERENCES

Block, R. J. \& Bolling, D. (I95I). The Amino Acid Composition of Proteins and Foods, 2nd ed. Springfield, Ill.: C. C. Thomas.

Eastoe, J. E. (1955). Biochem. F. 6r, 589 .

Elvehjem, C. A. (1956). F. Amer, diet. Ass. 32, 921 .

Graham, C. E., Smith, E. P., Hier, S. W. \& Klein, D. (1947). F. biol. Chem. r68, 711.

Harper, A. E. (1958). Ann. N.Y. Acad. Sci. 69, 1025.

Harvey, D. (1956). Tech. Commun. Bur. Anim. Nutr., Aberd., no. I9.

Hepburn, F. N., Lewis, E. W. Jr. \& Elvehjem, C. A. (1957). Cereal Chem. 34, 312.

Hughes, B. P. (1955). Brit. F. Nutr. 9, 373.

Hughes, B. P. (1958). Brit. F. Nutr. 12, 188.

McCance, R. A. \& Widdowson, E. M. (1946). Spec. Rep. Ser. med. Res. Coun., Lond., no. 235.

McDermott, E. E. \& Pace, J. (1957). Brit. Y. Nutr. II, 446.

Ministry of Agriculture, Fisheries and Food: National Food Survey Committee (1957). Domestic Food Consumption and Expenditure, 1955. London: H.M. Stationery Office.

Norris, F. W. (1958). Private communication.

Nunnikhoven, R. (1955). De aminozuur-sammenstelling van tarweeiwitten in verband met de uitmalingsgraad alsmede de instrumentatie voor kolom-chromatografie. Thesis, University of Amsterdam.

Orr, M. L. \& Watt, B. K. (1957). Home Econ. Res. Rep. U.S. Dep. Agric. no. 4.

Rose, W. C. (1957). Nutr. Abstr. Rev. 27, 631 .

Schram, E., Moore, S. \& Bigwood, E. J. (1954). Biochem. F. 57, 33.

Smith, E. L. \& Greene, R. D. (1948). F. biol. Chem. 172, I I 1 .

Watt, B. K., Merrill, A. L., Orr, M. L., Wu, W. T. \& Pecot, R. K. (r950). Agric. Handb. U.S. Dep. Agric. no. 8, p. 147.

\title{
Distribution of chromium sesquioxide and polyethyleneglycol in the reticulo-rumen of cattle
}

\author{
By J. L. CORBET'T, J. F. D. GREENHALGH AND E. FLORENCE \\ Rowett Research Institute, Bucksburn, Aberdeen
}

(Received 1о Yanuary 1959)

The results of an experiment reported in an earlier paper (Corbett, Greenhalgh, Gwynn \& Walker, I958) showed that there were large differences in the patterns of excretion in faeces of the water-soluble food marker polyethyleneglycol and the insoluble marker chromium sesquioxide $\left(\mathrm{Cr}_{2} \mathrm{O}_{3}\right)$ when these substances were administered simultaneously twice daily to dairy cows. It was suggested that these differences arose primarily from a differential distribution of the two markers in the contents of the reticulo-rumen; and that polyethyleneglycol was probably associated mainly with the liquid phase of digesta and so was cleared from these organs more rapidly than the $\mathrm{Cr}_{2} \mathrm{O}_{3}$ which, it was suggested, was associated primarily with the dry matter. This paper describes experiments to test this hypothesis.

\section{EXPERIMENTAL}

Two $2 \frac{1}{2}$-year-old barren dry Friesian heifers weighing about 750 and $1000 \mathrm{lb}$ (animals $176 \mathrm{~A}$ and $177 \mathrm{~B}$ respectively) were housed in loose-boxes with sawdust for bedding. They were given $400 \mathrm{~g}$ of grass-meal cubes containing about $7 \cdot \mathrm{r} \% \mathrm{Cr}_{2} \mathrm{O}_{3}$ 
and $12.5 \%$ polyethyleneglycol 4000 (Oxirane Ltd, Manchester) (PEG) twice daily, in Polythene bowls, at 09.30 and $17.00 \mathrm{~h}$. Immediately after the cubes were wholly consumed, that is after about $5 \mathrm{~min}$, the heifers were given half their daily ration of 20 and $26 \mathrm{lb}$, respectively, of baled dried grass (about $85 \%$ dry matter). Drinking water was available at all times.

A large fistula into the dorsal sac of the rumen had been established in both animals. The fistulas were closed with a rubber cannula and bung (Balch \& Johnson, 1948).

\section{Collection of samples}

Normally the material in the ventral rumen and in the reticulum is more or less liquid and includes food and residues from previous meals of small particle size. This liquid layer merges with more solid material in the dorsal rumen, which includes moist long roughage at various stages of microbial digestion. Samples of both types of digesta were obtained from several locations in the reticulo-rumen. They were taken from as nearly as possible the same positions at each sampling.

Samples from the rumen. Samples were obtained manually from the following locations: (I) the top layer of digesta in the dorsal rumen immediately above the point of entrance through the fistula, (2) the anterior dorsal sac within $7-8 \mathrm{~cm}$ of the cardia, (3) the posterior dorsal blind sac, (4) the anterior ventral blind sac, (5) the posterior ventral blind sac, and (6) the liquid phase of the digesta from the ventral rumen from a position immediately below the point of entrance through the fistula. Samples (3), (4) and (5) were taken from positions as far away from the point of entrance as could readily be reached. Solid samples from the ventral rumen were obtained without great difficulty from amongst the liquid digesta and resembled the samples obtained from the dorsal rumen. Samples (6) were taken in a small beaker closed by the palm of the hand during insertion and removal; they contained only very small amounts of the large particles of digesta, few exceeding $\mathrm{I} \mathrm{cm}$ in length.

Samples from the reticulum. A rubber tube was carried over the ruminoreticular fold to within $5 \mathrm{~cm}$ of the floor of the reticulum, and the required amounts of the liquid digesta from this organ, containing no large particles, were pumped out.

Faeces. Samples were taken manually from the rectum.

Sampling procedure. Solid digesta from the dorsal rumen and liquid digesta from the ventral rumen (sampling positions (I) and (6)) were obtained from heifer $\mathrm{i} 76 \mathrm{~A}$ at a fixed time on several days in order to study the distribution of the markers. In a preliminary study of the rates of change in marker concentrations, samples were drawn from the reticulum and from the rectum of heifer $176 \mathrm{~A}$ at frequent intervals during a $48 \mathrm{~h}$ period. Subsequently a more detailed study was made with heifer ${ }_{177} \mathrm{~B}$ when seven types of sample, taken from positions (2)-(6) inclusive in the rumen, from the reticulum, and from the rectum, were obtained on each of ten occasions during the course of a $24 \mathrm{~h}$ period. 


\section{Chemical methods}

Determinations of $\mathrm{Cr}_{2} \mathrm{O}_{3}$, on dried samples, and of PEG, on whole undried samples, were made by the methods previously described (Corbett, Greenhalgh, Gwynn \& Walker, 1958). The samples of liquid digesta were analysed soon after they were obtained; samples of the solid phase of digesta and of faeces awaiting analysis were stored in screw-topped waxed cardboard containers at $-20^{\circ}$.

\section{RESULTS}

The results obtained from the analysis of the two types of sample taken from the rumen of heifer $176 \mathrm{~A}$ at $16.30 \mathrm{~h}$ (i.e. $7 \mathrm{~h}$ after the morning dose of cubes and $\frac{1}{2} \mathrm{~h}$ before the afternoon dose) on each of 4 consecutive days are presented in Table I. Day-to-day variations in the composition of the samples did not obscure the very definite trends observed. The liquid and solid digesta showed a considerable difference in dry-matter content.

Table I. Concentrations of chromium sesquioxide and polyethyleneglycol in samples of the liquid phase of digesta from the ventral rumen, and in samples of the solid phase from the dorsal rumen, of heifer $176 \mathrm{~A}$.

(All samples taken at $\mathrm{I} 6.30 \mathrm{~h}$ on 4 successive days during a period of regular feeding and administration of markers)*

\begin{tabular}{|c|c|c|c|c|c|c|c|c|}
\hline \multirow[b]{2}{*}{ Type of digesta } & \multirow[b]{2}{*}{ Day } & \multirow{2}{*}{$\begin{array}{c}\text { Dry-matter } \\
\text { content } \\
(\%)\end{array}$} & \multicolumn{3}{|c|}{ Concentration of $\mathrm{Cr}_{2} \mathrm{O}_{3}$} & \multicolumn{3}{|c|}{ Concentration of PEG } \\
\hline & & & $\underset{\text { digesta }}{\mathrm{mg} / \mathrm{roog}}$ & $\begin{array}{c}\mathrm{mg} / \mathrm{g} \text { dry } \\
\text { matter }\end{array}$ & $\begin{array}{c}\mathrm{mg} / \mathrm{l} 00 \mathrm{~g} \\
\text { water }\end{array}$ & $\begin{array}{c}\mathrm{mg} / \mathrm{r} 00 \mathrm{~g} \\
\text { digesta }\end{array}$ & $\underset{\text { matter }}{\mathrm{mg} / \mathrm{g} \text { dry }}$ & $\begin{array}{c}\mathrm{mg} / 100 \mathrm{~g} \\
\text { water }\end{array}$ \\
\hline \multirow[t]{5}{*}{ Liquid } & $\mathbf{I}$ & $5 \cdot 7$ & $44 \cdot 2$ & $7 \cdot 7$ & $46 \cdot 9$ & $38 \cdot 3$ & $6 \cdot 7$ & 40.7 \\
\hline & 2 & $6 \cdot 5$ & $53 \cdot 8$ & $8 \cdot 3$ & $57 \cdot 5$ & $34^{\circ} 9$ & $5 \cdot 4$ & $37 \cdot 3$ \\
\hline & 3 & $4 \cdot 0$ & $35^{\circ} \circ$ & $8 \cdot \overline{8}$ & $36 \cdot 4$ & $38 \cdot 0$ & $9 \cdot 6$ & $39^{\cdot 6}$ \\
\hline & 4 & $3 \cdot 7$ & $3 I \cdot 4$ & $8 \cdot 4$ & $32 \cdot 7$ & $37 \cdot 1$ & $9^{\circ} 9$ & $38 \cdot 5$ \\
\hline & Mean & $5 \cdot 0$ & $4 I \cdot I$ & $8 \cdot 3$ & 43.4 & $37 \cdot 1$ & $7 \cdot 9$ & $39^{\circ} 0$ \\
\hline \multirow[t]{5}{*}{ Solid } & $\mathbf{I}$ & $15 \cdot 5$ & $73 \cdot 6$ & $4 \cdot 7$ & $87 \cdot I$ & $30 \cdot 0$ & $x \cdot 9$ & $35^{\circ} 4$ \\
\hline & 2 & $\times 5 \cdot 3$ & $72 \cdot 3$ & 4.7 & $85 \cdot 4$ & $29^{\circ} I$ & $I \cdot 9$ & $34 \cdot 4$ \\
\hline & 3 & $16 \cdot 3$ & $57 \cdot 1$ & $4 \cdot 0$ & $68 \cdot 2$ & $28 \cdot 2$ & $I \cdot 7$ & $33 \cdot 7$ \\
\hline & 4 & $16 \cdot 9$ & $77 \cdot 7$ & $4 \cdot 6$ & 93.5 & $29 \cdot 7$ & $\mathrm{I} \cdot 8$ & $35^{\circ} 8$ \\
\hline & Mean & $16 \cdot 0$ & $70 \cdot 2$ & $4 \cdot 5$ & $83 \cdot 6$ & 29.2 & $\mathrm{I} \cdot 8$ & $34 \cdot 8$ \\
\hline
\end{tabular}

* $28 \mathrm{~g} \mathrm{Cr}_{2} \mathrm{O}_{3}$ and $50 \mathrm{~g} \mathrm{PEG}$ in grass-meal cubes were given twice daily at 09.30 and $\mathrm{r} 7.00 \mathrm{~h}$.

The concentrations of PEG in relation to water in the two types of sample were very similar and showed a relatively small degree of variability. On the other hand, concentrations of PEG in the dry matter tended to vary inversely with the dry-matter content of the sample and the ratios for the values for liquid and solid digesta, respectively, varied between about $3: 1$ and $6: x$. These results would be expected if the distribution of a substance in the rumen contents was similar to that of water.

The concentrations of $\mathrm{Cr}_{2} \mathrm{O}_{3}$ in relation to water were much more variable than those of PEG both within and between types of sample, but the distribution was much more regular when calculated on a dry-matter basis. Although concentrations of $\mathrm{Cr}_{2} \mathrm{O}_{3}$ in the dry matter of liquid and solid digesta were approximately in the proportion $2: \mathrm{I}$, 
this ratio was fairly constant and the values within each type of sample did not vary greatly.

Results for the digesta as sampled show that, per unit weight, the solid digesta contained a greater weight of $\mathrm{Cr}_{2} \mathrm{O}_{3}$, but a smaller weight of $\mathrm{PEG}$, than the liquid digesta.

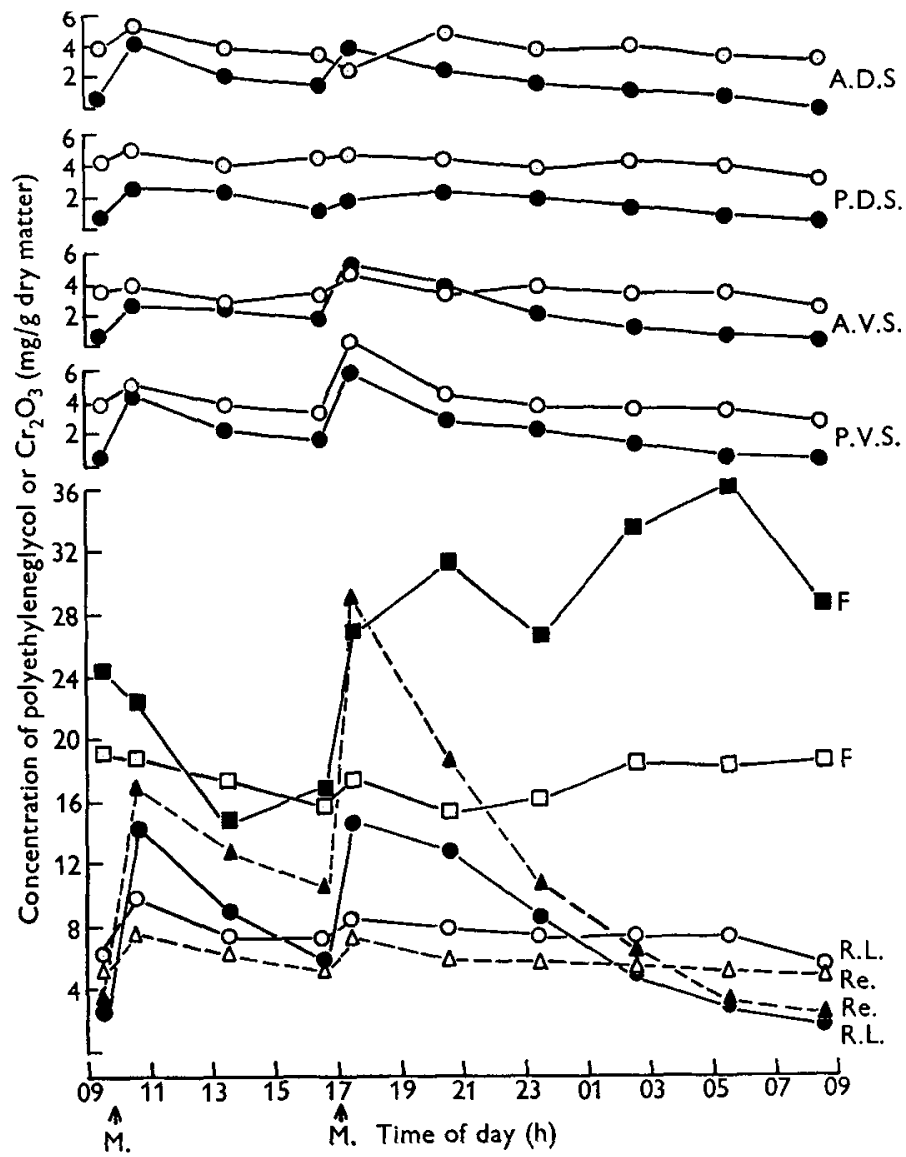

Fig. 1. Concentration of polyethyleneglycol (solid symbols) and of chromium sesquioxide (open symbols) in samples of digesta from six locations in the reticulo-rumen of heifer $177 \mathrm{~B}$ (see p. 338) and in faeces. The locations sampled and the mean daily dry-matter contents of the samples were: anterior dorsal sac (A.D.S.), I5.5\%; posterior dorsal blind sac (P.D.S.), 16.5\%; anterior ventral blind sac (A.V.S.), I $4.4 \%$; posterior ventral blind sac (P.V.S.), $15.3 \%$; ventral rumen, rumen liquor (R.L.), $4.7 \%$; reticulum, digesta (Re.), 3.5\%; rectum, faeces (F), 18.7\%. Times of giving markers (M.) are shown by arrows.

Results for the samples obtained from heifer $176 \mathrm{~A}$ during the $48 \mathrm{~h}$ period are not reported because they were fully confirmed by the results of the more detailed investigations made with heifer $177 \mathrm{~B}$. The diurnal changes in marker concentrations in the dry matter of the seven types of sample obtained from heifer $177 \mathrm{~B}$ are shown in Fig. I ; the mean dry-matter content of each type of sample is also given. In confirmation of the results obtained with heifer $176 \mathrm{~A}$, concentrations of $\mathrm{Cr}_{2} \mathrm{O}_{3}$ in the solid digesta of heifer $177 \mathrm{~B}$ were higher than those of $\mathrm{PEG}$ in all but three samples, although 
the weights of $\mathrm{Cr}_{2} \mathrm{O}_{3}$ and $\mathrm{PEG}$ consumed were in the proportion $\mathrm{r}: \mathrm{r} \cdot 8$. In addition, concentrations of PEG in the dry matter of the rumen liquor and of the reticulum samples were from four to eight times as great as the values recorded at the same times for the solid digesta, whereas the $\mathrm{Cr}_{2} \mathrm{O}_{3}$ concentrations were about twice as great.

All four types of sample of the solid digesta showed the same general pattern of variation in marker concentration. There were differences in the details of the patterns, and the variations in samples from the ventral rumen tended to be greater than in those from the dorsal rumen; variations in the posterior dorsal blind sac were relatively small. Variations in PEG concentration were much greater than those of $\mathrm{Cr}_{2} \mathrm{O}_{3}$, and within types of sample the maximum $P E G$ values recorded were from eleven to twenty-four times their minimum values. Maximal $\mathrm{Cr}_{2} \mathrm{O}_{3}$ concentrations were at the most three times the minimal.

The degree of variation in the concentrations of the markers in the rumen-liquor and in the reticulum samples was similar to that in the samples of solid digesta though, with PEG especially, the variations were more obvious because of the larger amounts present. Concentrations of $\mathrm{Cr}_{2} \mathrm{O}_{3}$ in the reticulum samples $(3.5 \%$ dry matter) were always lower than those in the corresponding rumen-liquor samples (4.7\% dry matter) but, in concordance with the water contents, this situation was reversed with PEG. The peak PEG concentrations in the reticulum and rumen liquor were higher after the afternoon dose of markers than after the morning dose, probably because the afternoon samples were obtained only $\frac{1}{2} \mathrm{~h}$ after the dose whereas in the morning $\mathrm{I} \mathrm{h}$ elapsed between the giving of the dose and the taking of the samples. Thus the morning peak had probably passed before the measurements were made. The same trend could be discerned in the $\mathrm{Cr}_{2} \mathrm{O}_{3}$ concentrations in the samples obtained from the reticulum of heifer $176 \mathrm{~A}$ during the two $24 \mathrm{hr}$ periods referred to above, but was not apparent for samples obtained from the reticulum of heifer $177 \mathrm{~B}$.

The variations in PEG concentrations would, to some degree, tend to be exaggerated compared with those for $\mathrm{Cr}_{2} \mathrm{O}_{3}$ because the weight of $\mathrm{PEG}$ consumed in each lot of cubes was about $80 \%$ greater than the weight of $\mathrm{Cr}_{2} \mathrm{O}_{3}$. PEG was given at an average rate of about $10 \mathrm{mg} / \mathrm{g}$ food dry matter and the values in the reticulum varied between 22 and $290 \%$ of this figure. In rumen liquor they varied between 19 and $147 \%$ and in solid digesta between 2 and $57 \%$ of it. Calculated on this basis, the $\mathrm{Cr}_{2} \mathrm{O}_{3}$ concentrations were still much less variable. In the reticulum they were 90$130 \%$, in rumen liquor $100-174 \%$ and in solid digesta $4 \mathrm{I}-\mathrm{I} 37 \%$ (or $4 \mathrm{I}-92 \%$ if one high value recorded in the posterior ventral sac at $17.30 \mathrm{~h}$ is excluded) of the mean consumption of about $5.7 \mathrm{mg} \mathrm{Cr}_{2} \mathrm{O}_{3} / \mathrm{g}$ food dry matter.

The concentrations of PEG in the water of the six samples from the reticulorumen are shown in Table 2. With the exception of the first lot of samples taken after each of the two doses of markers, the values at any given time showed a remarkable degree of similarity.

In the dry matter of faeces the maximum deviations of marker concentrations in individual samples from the mean concentrations in the ten samples were $+3^{8}$ and $-44 \%$ for $\mathrm{PEG}$ and +9 and $-13 \%$ for $\mathrm{Cr}_{2} \mathrm{O}_{3}$. These figures show good agreement 
with those reported for the earlier experiment with cows (Corbett, Greenhalgh, Gwynn \& Walker, I958). There were no obvious peaks in the $\mathrm{Cr}_{2} \mathrm{O}_{3}$ excretion curve, but there were two peaks in the PEG curve separated by a $7-9 \mathrm{~h}$ interval.

Table 2. Concentrations of polyethyleneglycol ( $\mathrm{mg} / \mathrm{100} \mathrm{g}$ water) in samples of digesta taken from six locations in the reticulo-rumen of heifer ${ }_{777} B$ at intervals during $a$ $24 h$ period

\begin{tabular}{|c|c|c|c|c|c|c|}
\hline \multirow[b]{2}{*}{ Time* } & \multicolumn{2}{|c|}{ Liquid digesta } & \multicolumn{4}{|c|}{ Solid digesta from the rumen } \\
\hline & Reticulum & $\begin{array}{l}\text { Ventral } \\
\text { rumen }\end{array}$ & $\begin{array}{c}\text { Anterior } \\
\text { dorsal }\end{array}$ & $\begin{array}{c}\text { Posterior } \\
\text { dorsal }\end{array}$ & $\begin{array}{l}\text { Anterior } \\
\text { ventral }\end{array}$ & $\begin{array}{c}\text { Posterior } \\
\text { ventral }\end{array}$ \\
\hline 09.30 & I $5 \cdot 0$ & $14 \cdot 8$ & $11 \cdot 4$ & I $1 \cdot 8$ & $10 \cdot 0$ & $9 \cdot 8$ \\
\hline 10.30 & $67 \cdot 6$ & $83 \cdot 5$ & $74 \cdot 3$ & $49 \cdot 3$ & $50 \cdot 3$ & $83 \cdot 6$ \\
\hline $13 \cdot 30$ & $45^{\circ} \circ$ & $43 \cdot I$ & $36 \cdot 4$ & 43.4 & $39^{\circ} 0$ & $40 \cdot 6$ \\
\hline 16.30 & $30 \cdot 0$ & $29 \cdot 6$ & $24 \cdot 4$ & $26 \cdot 8$ & $24 \cdot 9$ & $25 \cdot 4$ \\
\hline $17 \cdot 30$ & 100.4 & $78 \cdot 1$ & $7 x \cdot 7$ & $34 \cdot 3$ & $84 \cdot 8$ & I I I 0 \\
\hline $20 \cdot 30$ & $5 I \cdot 4$ & $53 \cdot 0$ & $46 \cdot 6$ & $48 \cdot I$ & $50 \cdot 8$ & $49 \cdot 1$ \\
\hline $23 \cdot 30$ & $36 \cdot 1$ & $38 \cdot 5$ & $27 \cdot 0$ & $34 \cdot 6$ & $33 \cdot 5$ & $36 \cdot 3$ \\
\hline 02.30 & $2 \mathrm{I} \cdot 4$ & $23 \cdot 0$ & $19 \cdot 2$ & $23 \cdot 4$ & $17 \cdot 3$ & $21 \cdot 4$ \\
\hline $05 \cdot 30$ & I 3.6 & $14^{\circ} \mathrm{O}$ & $9^{\circ} \mathbf{I}$ & $12 \cdot 6$ & 10.7 & $9 \cdot 2$ \\
\hline 08.30 & $8 \cdot 8$ & $8 \cdot 4$ & $4 \cdot 8$ & $3 \cdot 8$ & $4^{*} 9$ & $4 \cdot \mathrm{I}$ \\
\hline
\end{tabular}

* $28 \mathrm{~g} \mathrm{Cr}_{2} \mathrm{O}_{3}$ and $50 \mathrm{~g} \mathrm{PEG}$ in grass-meal cubes were given immediately after the $09.30 \mathrm{~h}$ samples had been taken and again at $17.00 \mathrm{~h}$.

\section{DISCUSSION}

It is recognized that, in the analysis of PEG, difficulties which we have not resolved, and which tend to result in underestimation of this substance (Corbett, Greenhalgh, Gwynn \& Walker, 1958; Christie \& Lassiter, I958), may render the actual values for PEG concentrations unreliable, but it is very unlikely that the results obtained and the conclusions drawn from them would be significantly altered if a more precise method of analysis, such as that suggested by Smith (1958), could have been used.

Because the patterns of excretion of the markers in faeces found in the investigation reported here were very similar to those reported earlier (Corbett, Greenhalgh, Gwynn \& Walker, 1958) it is probable that the distribution and behaviour of the markers in the reticulo-rumen of the two lots of cattle were also similar. The results presented have confirmed that PEG is associated mainly with the water in the digesta and that, as a consequence, its concentration in the reticulo-rumen declines rapidly after its administration because the liquid digesta contain the greatest weight of PEG and probably pass relatively rapidly through the reticulo-omasal orifice.

The solid digesta as sampled contained, weight for weight, larger amounts of $\mathrm{Cr}_{2} \mathrm{O}_{3}$ than the liquid digesta, which suggests an association of $\mathrm{Cr}_{2} \mathrm{O}_{3}$ with dry matter. No information on the nature of this association was obtained. Microscopic examination under polarized light of digesta from the duodenum of a sheep dosed with a gelatin capsule containing $\mathrm{Cr}_{2} \mathrm{O}_{3}$ powder (Corbett, Greenhalgh \& MacDonald, I958) did not reveal a close association of $\mathrm{Cr}_{2} \mathrm{O}_{3}$ with particles of digesta in this part of the gut. It was not possible to make a similar examination of material from the reticulorumen of the cattle used in the experiment now reported because the particles of digesta were far too large for microscopy. 
The remarkable similarity between samples from the reticulo-rumen in the concentrations of PEG in the water they contained is an interesting indication of the extent to which the liquor in this organ is mixed and circulated. The mixing, however, would probably not disperse a dose of PEG, given as the solid by mouth or inserted into the rumen, sufficiently well to allow critical studies by this means on the fate of other solutes. Circulation of rumen liquor may have played a considerable part in the distribution of $\mathrm{Cr}_{2} \mathrm{O}_{3}$, and the higher concentrations in the liquid than in the solid digesta, expressed on a dry-matter basis, are probably a reflection of the small particle size of this marker. The form in which $\mathrm{Cr}_{2} \mathrm{O}_{3}$ was administered, in grass-meal cubes, may also have assisted in its distribution, for in none of the samples of digesta were the variations in concentration as great as those reported by Balch, Reid \& Stroud (1957) for digesta from the region of the reticulo-omasal orifice of steers. These workers administered smaller doses of $\mathrm{Cr}_{2} \mathrm{O}_{3}$ which were contained in gelatin capsules. A survey of the many reports on the use of $\mathrm{Cr}_{2} \mathrm{O}_{3}$ provides support for their suggestion that when given in this form it is excreted less evenly in the faeces than when it is given mixed with some other material, probably because a capsule disintegrates in the anterior rumen or reticulum resulting in the rapid transfer of local concentrations of $\mathrm{Cr}_{2} \mathrm{O}_{3}$ through the reticulo-omasal orifice.

A re-examination of some radiographs showing the fate of gelatin capsules containing $\mathrm{Cr}_{2} \mathrm{O}_{3}$ administered by mouth to sheep (Corbett, Miller, Clarke \& Florence, 1956, and unpublished observations) and further investigations of this type where the abomasum was shadowed with a barium-sulphate drench (in cow's milk), showed that the capsules lodged in the anterior rumen or reticulum and did not, as reported earlier, enter the omasum or abomasum. Concentrations of $\mathrm{Cr}_{2} \mathrm{O}_{3}$ released from these capsules were observed in the reticulum, anterior dorsal rumen sac and the anterior region of the ventral rumen sac, and the marker was observed streaming through the omasal-abomasal orifice within i $\mathrm{h}$ after dosing. When, however, standard capsules of $\mathrm{Cr}_{2} \mathrm{O}_{3}$ were inserted regularly, by fistula, directly into the rumen of sheep the variations in $\mathrm{Cr}_{2} \mathrm{O}_{3}$ concentrations in their faeces did not appear to be less than those found with similar sheep given the same doses of $\mathrm{Cr}_{2} \mathrm{O}_{3}$ by mouth, though the pattern of excretion appeared to be more regular.

When $\mathrm{Cr}_{2} \mathrm{O}_{3}$ is given mixed with some other material it may be carried into the rumen and become mixed with digesta. Crampton \& Lloyd (I95 I) concluded that sheep receiving roughage rations should preferably be given doses of $\mathrm{Cr}_{2} \mathrm{O}_{3}$ mixed with a small quantity of ground food. More recent work (Corbett, Greenhalgh \& MacDonald, r958) suggests that paper may be a very satisfactory carrier for $\mathrm{Cr}_{2} \mathrm{O}_{3}$.

The $\mathrm{Cr}_{2} \mathrm{O}_{3}$ in the marker cubes was apparently not carried very rapidly to the posterior dorsal blind sac and the results for both $\mathrm{Cr}_{2} \mathrm{O}_{3}$ and PEG suggest that the rate of change of digesta in this part of the rumen, at least in the location sampled, was less rapid than in other parts of the rumen.

The rate at which the concentrations of PEG and of $\mathrm{Cr}_{2} \mathrm{O}_{3}$ in the dry matter in the reticulo-rumen appeared to decline was probably increased by the diluting effect of the dried grass consumed immediately after the dose of markers. This increase is possibly the explanation for the observation made by Balch et al. (I957) that $\mathrm{Cr}_{2} \mathrm{O}_{3}$ 
concentrations in digesta from the region of the reticulo-omasal orifice, following the increase after the administration of $\mathrm{Cr}_{2} \mathrm{O}_{3}$, declined during feeding and afterwards increased. Such changes were not found in our experiment, but it was observed (Corbett, unpublished) that during a period of relatively constant concentration of $\mathrm{Cr}_{2} \mathrm{O}_{3}$ in digesta drawn from the duodenum of a sheep there was a transient depression in concentration shortly after a meal. Irregularities in $\mathrm{Cr}_{2} \mathrm{O}_{3}$ concentrations in faeces from grazing animals are greater than in faeces from hand-fed animals (Hardison \& Reid, I953; Raymond \& Minson, I955), probably because the pattern of feeding on pasture, which is altered by many circumstances, has very irregular effects upon the concentrations in the reticulo-rumen.

Balch et al. (1957) suggested that the effects of events in the reticulo-rumen upon $\mathrm{Cr}_{2} \mathrm{O}_{3}$ concentrations in faeces are reduced by the mixing of the digesta that occurs after they leave that organ. Results for heifer $\mathrm{I}_{77} \mathrm{~B}$ support their reasoning, for the maximum concentrations of $\mathrm{PEG}$ and $\mathrm{Cr}_{2} \mathrm{O}_{3}$ in the dry matter in the reticulo-rumen were up to twenty-four and three times the minimum values respectively, but the maximum concentrations in the faeces dry matter were only 2.5 and $r \cdot 2$ times the minimum values respectively.

The interval of $7-9 \mathrm{~h}$ between the two peaks in PEG concentration in faeces, observed in both animals used in this study, is similar to that $\left(7 \frac{1}{2} \mathrm{~h}\right)$ separating the consumption of the marker cubes. It may be presumed that the first peak is related to the morning dose of PEG and the second to the afternoon dose, which suggests that the PEG in solution took ro-r $2 \mathrm{~h}$ to pass from the region of the reticulo-omasal orifice to the rectum. This estimated time of passage is shorter than the estimates made by Balch (1950) of the time taken for stained particles of hay to pass through the hind gut of dairy cows, which he obtained by placing the particles directly into the abomasum and from the ' $5 \%$ excretion time' of particles given with the food, but is in general agreement with the $5 \%$ excretion time for single large doses of PEG given to steers in another experiment (Corbett, Gwynn, Walker \& Aitken, I958). There were no reference points in the $\mathrm{Cr}_{2} \mathrm{O}_{3}$ excretion curves that would allow similar calculations to be made for this marker.

\section{SUMMARY}

I. Two fully-grown heifers with large rumen fistulas were given $400 \mathrm{~g}$ grassmeal cubes containing about $7 \cdot 1 \% \mathrm{Cr}_{2} \mathrm{O}_{3}$ and $12 \cdot 5 \%$ polyethyleneglycol 4000 (PEG) and a ration of baled dried grass, in that order, twice daily.

2. Samples of solid digesta ( $6 \%$ dry matter) from the dorsal rumen and of liquid digesta ( $5 \%$ dry matter) from the ventral rumen of one animal were obtained at a fixed time on several days. The solid digesta contained larger amounts of $\mathrm{Cr}_{2} \mathrm{O}_{3}$ but smaller amounts of $\mathrm{PEG}$ than the liquid digesta. The concentrations of $\mathrm{PEG}$ in the water in the two types of digesta were very similar; on the other hand, the distribution of $\mathrm{Cr}_{2} \mathrm{O}_{3}$ approximated to that of the dry matter.

3. Samples of solid digesta from four locations in the rumen, of liquor from the ventral rumen, of digesta from the reticulum, and of faeces were obtained from the second animal on ten occasions during a $24 \mathrm{~h}$ period. The results showed that PEG, 
because of its association with the water in the digesta, was cleared from the reticulorumen much more rapidly than $\mathrm{Cr}_{2} \mathrm{O}_{3}$, giving rise to wider variations in the concentration of PEG in the dry matter of faeces.

The two animals used in this investigation were kindly made available to us by Dr A. T. Phillipson. One of us (J.F.D.G.) is in receipt of a Drummond Junior Fellowship for Research in Nutrition.

\title{
REFERENCES
}

Balch, C. C. (1950). Brit. F. Nutr. 4, 36I.

Balch, C. C. \& Johnson, V. W. (1948). Vet. Rec. 6o, 446.

Balch, C. C., Reid, J. T. \& Stroud, J. W. (1957). Brit. F. Nutr. 11, 184.

Christie, L. E. \& Lassiter, G. A. (1958). Quart. Bull. Mich. agric. Exp. Sta. 40, 714.

Corbett, J. L., Greenhalgh, J. F. D., Gwynn, P. E. \& Walker, D. (1958). Brit. F. Nutr. 12, 266.

Corbett, J. L. Greenhalgh, J. F. D. \& MacDonald, A. P. (1958). Nature, Lond., 182, I014.

Corbett, J. L., Gwynn, P. E., Walker, D. \& Aitken, J. N. (1958). F. Brit. Grassl. Soc. 13, 137.

Corbett, J. L., Miller, T. B., Clarke, E. W. \& Florence, E. (1956). Proc. Nutr. Soc. r5, v.

Crampton, E. W. \& Lloyd, L. E. (I95I). F. Nutr. 45, 3 I 9.

Hardison, W. A. \& Reid, J. T. (1953). F. Nutr. 5r, 35 .

Raymond, W. F. \& Minson, D. J. (1955). F. Brit. Grassl. Soc. 10, 282.

Smith, R. H. (1958). Nature, Lond., 182, 260.

\section{The effect on chick growth of inactivated penicillin, mineral sulphates or furazolidone supplements}

\author{
By M. E. COATES AND G. F. HARRISON \\ National Institute for Research in Dairying, Shinfield, Reading
}

(Received 27 Fanuary 1959)

The growth-promoting effect of antibiotics for chicks, under certain conditions, has been firmly established for several years, and the literature on this subject has been extensively reviewed (Taylor, I957; Braude, Kon \& Porter, I953).

Other materials have also been tested for growth-promoting activity. Thus, claims have been made that inactivated penicillin or its degradation products (Jukes, I956; Wacker, Heyl, Büechl \& Holthoff, I955, I956), copper sulphate or potassium sulphate (Wacker et al. 1956), sodium sulphate (Gordon \& Sizer, I955) or furazolidone (Mellen $\&$ Waller, I954; Berg, Hamilton \& Bearse, 1956) can stimulate the growth of chicks.

We report here experiments in which we have investigated these claims.

EXPERIMENTAL AND RESULTS

Management of chicks

Day-old Rhode Island Red $\times$ Light Sussex cockerels were used in all experiments but one, for which only pullets were available. The birds were housed in electrically heated tier brooders, in a room where a growth response to penicillin had been obtained 